\title{
Loopholes in Environmental Laws Allow for Incomplete Remediation Thwarting Environmental Sustainability
}

\author{
Renee A. Pistone \\ Candidate, Harvard University Environmental Management Graduate Program; Alternative Dispute Resolution \\ (ADR) Legal Specialist \& Practitioner, B\&R Associates \\ Faculty, Rutgers University Writing Program, New Brunswick, NJ USA
}

\begin{abstract}
At least 103 children in Toms River, Dover Township, New Jersey had been diagnosed with cancer in what is believed to be the nation's largest child cancer cluster. In 1995, a state study found that incidence of cancer among children in Toms River was higher than any other part of the state. In Dover Township, it was reported that 90 children were found to have various types of cancer between 1979 and 1995. Since the original cases,

28 more children there have been found to have cancer, the families said. Over a period of decades, chemical plants, including ones owned by Ciba-Geigy released industrial pollutants into the Toms River. Industrial pollutants leached into the township's groundwater supply. The pollutants included chemicals used in the manufacture of epoxies, resins, and dyestuffs. In 1983, the United States Environmental Protection Agency (USEPA) listed the site on the Superfund National Priorities List that includes the country's most polluted sites. Remediation is now underway at the site and is expected to be completed by the end of 2010 . The remediation efforts do not include removal of all the drums. The drums should not be left there in order to keep costs down. The problem here is that loopholes in the law regarding how remediation is carried out in New Jersey allow for too much agency discretion. The compromises that are made between state officials and businesses to lower remediation costs should never raise the citizen's health risk. This compromise means that drums will be left on-site. The drums will leak again and it is just a matter of time. Leaving the drums there is a danger, an unnecessary risk that leaves children at risk for further injuries. In short, this case study is an example of the large barriers preventing sustainability at the regional level.
\end{abstract}

Keywords: Sustainability, Industrial pollutants, Cancer cluster, Superfund

\section{Introduction}

The Ciba-Geigy Corporation site is surrounded by residential and light commercial areas that are part of the containment problem stemming from the chemical manufacturing plant's occupation. During the period 1952 through 1966, treated process wastewater was discharged directly into the Toms River. Solid and liquid wastes, including by-products from chemical dyes, epoxy resins manufacturing processes, and wastewater treatment sludge, were disposed of in approximately 20 on-site areas (Environmental Protection Agency, 1993). Ciba-Geigy, as a superfund site, is on the National Priorities List (NPL) demonstrating the expansiveness of the pollution (Ciba-Geigy, 1988). The Environmental Protection Agency (EPA) identifies sites in the United States for clean up because the sites are harmful to human health and the environment. Under the Comprehensive Environmental Response Compensation and Liability Act (CERCLA) parties who pollute are held responsible for remediation (CERCLA, 2000). Hence, Ciba-Geigy, as a party responsible for polluting, had to pay under CERCLA's mandate. The Resource Conservation and Recovery Act (RCRA, as amended in 2000) is the law that provides the procedures to be followed for these clean ups. The Act allows the State of New Jersey to regulate the landfill giving it some control. RCRA functions as a corrective action program designed to require treatment of wastes prior to disposal. In March 2001, Ciba-Geigy entered into a consent decree with EPA to implement the source area cleanup at an estimated cost of $\$ 90$ million. It called for removal of the stacked drums which was completed in November, 2004. Also, approximately 7 billion gallons of contaminated groundwater had been treated to meet EPA standards and soil treatment ended in 2008. Interestingly, EPA area remediation plans are generally expected to be completed in less than three years. Part I of this article reveals the crux of the region's problem delving into the environmental and public health risks. Part II explores the relevant regional laws and their shortcomings, as they relate to this Superfund site's remediation plan. Part III concludes with recommendations for actions necessary to reduce risks promoting environmental sustainability.

\subsection{Background}

The site is located in Dover Township, New Jersey approximately one mile west of the Garden State Parkway in Ocean County. It is three miles West of the business district and it borders Winding River Park. Winding River Park is a public outdoor recreational area serving the 10,000 residents who are within one mile. Winding River Park is a place where families congregate for water sports activities and picnics. Young children often played on the swing sets and in the sand boxes there. There is a residential area on the Eastern side with single-family homes. Pine Lake Park Estates is additional residential housing in Manchester Township and it borders the northwest section of the site. West Dover elementary school is south of the site. 


\subsection{Demographics}

We should consider the demographics along with the aforementioned child cancer rates mentioned in the summary section. There are 855 children aged 6 and under living within one mile of the site. At least 103 children developed cancer during the period of 1979 to 1995 . In later years 28 more children developed cancer. There were 16 children who died from cancer. It is staggering to consider that there are 4,300 housing units within one mile from the site (United States Environmental Protection Agency, 1989). The Ciba-Geigy Plant began producing anthraquinone-based dyes in 1952. By 1959, it made azo dyes and epoxy resins. All manufacturing operations ended at the end of 1996 and dye manufacturing ceased in 1988 according to the EPA Listing. The manufacturing processes generated both liquid and solid wastes. There were 31,000 drums disposed of in a landfill. There was a five-acre lime sludge disposal area. There were numerous lagoons and wastewater treatment plants comprising 30 acres. Solid waste was disposed in drums and wastewater treatment sludge was stockpiled on the landfill on site. Treated wastewater (the extraction of metals and organic chemicals) was discharged directly into the Toms River. In 1966, treated wastewater was discharged into the Atlantic Ocean through the underground pipeline that ran through mainland Dover Township. They had a permit for ocean dumping (Ciba-Geigy, 1988). This case concerns whether proper administrative procedures were followed in connection with the issuance of the permit to discharge about 5.9 million gallons daily of chemically treated effluent into the Atlantic. The usage of the pipeline ended in 1991 due to concerns about leakage (Agency for Toxic Substances \& Disease Registry, 1998).

\section{Ground Water Is Still Threatened Resulting In Continued Public Health Risks}

The first Public Health Assessment at the site was completed by the Agency for Toxic Substances and Disease Registry (ATSDR) in 1988. The ATSDR concluded that there were public health concerns and risks to human health. It is asserted here that because the site's remediation plan allows for some drums to be left behind, the public health risk levels remain high. There is a high potential for these drums to leak into groundwater, over time. The importance of groundwater, as a vital natural resource, cannot be underscored enough (Thomas, 2009). Our communities' underground aquifers supply water that is extracted for use in residential homes and schools. The control of water continues to be an issue worldwide and contaminated groundwater can travel freely between states and regions (Benedict, 2009). The Agency tested the surface waters of the Toms River within Winding River Park and levels were not threatening. Later on, the agency released an addendum in 1991 as it found trace elements of contaminants in the soil. Contaminants that were identified were benzene, nitrobenzene, vinyl chloride, and methylene chloride. These contaminants cause illness and death and there must be a point of human exposure. Adults and children and people who worked at the plant became ill and some died from these contaminants. Here, the route of exposure was traced back to pollution of the site. Finally, there must be a receptor population who could come into contact with hazardous substances. At the Ciba-Geigy site there were people who worked there and people living within a mile of the site that were exposed (New Jersey Department Health and Senior Services, 1997). The EPA asserts that it has eliminated disease causing exposure pathways, in this case, since the pipeline was shut down leading to the Atlantic Ocean. And it cleaned up the site's drums (AWARE, 1985) but this ignores the current danger as the remaining drums, left at the site, will leak. Because people died and this threat is ongoing, this article will evaluate specific exposure pathways considering the private wells, the oceanic pipeline, community water supply well at Holly Street, airborne contaminants, and surface water and soil. They may have tried to stop the groundwater contamination. In 1985, Ciba-Geigy installed a purge-well system to intercept contaminated groundwater that traveled into the residential area. The goal was to achieve either 5 or $50 \mathrm{ug} / 1$ to meet New Jersey Surface Water Quality Standards for metals and dissolved solids. The plan was to extract and treat about 4 million gallons a day of contaminated groundwater from the Upper Sand Aquifer under the Ciba-Geigy site. It was decided that all treated groundwater would be directed to the northeast recharge area to avoid contamination of community water supply wells located east of Toms River. There are several applicable laws that Congress passed, but once implemented, fall short of adequately dealing with such risks to environmental sustainability.

\section{Traditional Environmental Laws Fail to Promote Environmental Sustainability}

Congress enacted the Comprehensive Environmental Response, Compensation and Liability Act (CERCLA) to impose strict liability on polluters, forcing polluters rather than taxpayers, to pay all clean up costs. Under CERCLA section 107(a), a site meets the Act's qualifications: when an actual or potential pollution occurs, when the facility has a polluter who may be held accountable, and when the aggrieved party has paid to clean up the pollution. CERCLA is the controlling law when it comes to handling Superfund sites like Ciba-Geigy. This federal law applies to states and other plaintiffs as long as a prima facie case is met under CERCLA's section 107(a) qualifications. CERCLA functions with the NPL as a site must be serious enough to warrant being ranked on the NPL in order to gain Superfund financial assistance, through CERCLA. The Act provides two basic ways that sites that can be cleaned up. First, the EPA may take action and then obtain reimbursement for its remediation efforts from the polluter. Under this scenario, the EPA taps into the Superfund money, and it later replenishes that money, after the polluter pays the EPA back. One main problem is that CERCLA has also struggled to carry out its mandate due to issues of under-funding in recent years (Adams, 2008). 


\subsection{EPA Fee Sharing Arrangements}

Alternatively, the state files suit against a responsible party or it may join the EPA in a fee sharing arrangement. This approach is more problematic since the state cannot seek injunctive relief, (a remedy that is available only to the federal government); therefore, the state has to wait for reimbursement of its remediation costs. What happened at the Ciba-Geigy site seemed to be somewhat of a hybrid of these two approaches. The Ciba-Geigy site's remediation plan took effect when Ciba-Geiby entered into a consent decree with the EPA, to implement a clean up costing millions. The compromises that stemmed from the EPA and Ciba-Geigy's agreement led to an incomplete remediation. If the EPA carried out the remediation efforts itself, and borrowed from the Superfund, it would have held Ciba-Geigy responsible for the full dollar amount, of what a complete remediation costs. The agreement that grants Ciba-Geigy permission to leave some drums on site, renders the remediation project incomplete. This is how implementing CERCLA as a legal remedy falls short of what is expected in remediation efforts, even though, it may bring polluters to justice. In short, the greater shortcoming is that CERCLA does nothing to promote environmental sustainability because incomplete remediation plans are a lasting and future environmental hazard.

\subsection{CERCLA and Its Many Shortcomings}

While, the Act strives to hold polluters, rather than taxpayers, financially accountable for remediation efforts, it does not properly set guidelines for how remediation is carried out. It in this manner, it falls short, because the EPA should be carrying out the remediation plans, and then holding the polluter responsible for the costs of doing it the right way. When the law allows for the polluter to clean up the waste, polluters will find the less costly means of doing so. CERCLA gives states less power to address pollution at home, as the state cannot seek injunctive relief. It makes more sense for the EPA to take the leading role: by borrowing from the Superfund, by seeking injunctive relief, and by holding polluters responsible. The Act is designed to give the federal government more authority than the states and states need more power at the local level, since states ultimately deal with the loss of natural resources from rampant pollution. We cannot deal with these issues with a short term framework in mind. It is necessary to consider the long term effects of our remediation efforts. Complete remediation plans that do not plan for the future are toothless and therefore, rendered incomplete. As a consequence, our children's children will face these issues and suffer from our failure to complete the remediation and to foster environmental sustainability.

\subsection{Clean Up Rules Under RCRA, Need to Be Cleaned Up}

The Resource Conservation and Recovery Act (RCRA) contains the procedures that are followed during the clean up of waste sites. The Program lacks any sort of flexibility providing for generic solutions that translate into a set of national rules, requiring a specific waste management technology without regard to a local sites' unique challenges and problems. The RCRA Program is good at deterring polluters, but far less effective when dealing with existing sludge, or in this case, Ciba-Geigy's contaminated soil and water problems. The problematic components include the delays that are caused: by the permit procurement process, by the implementation of requirements to treat waste prior to land disposal, and by the requirements to employ specific hazardous waste technologies. Ciba-Geigy is an example whereby regulators, must have some level of flexibility, to approve site-specific remediation efforts that reduce environmental exposures to waste. Expensive treatment is not always congruent with actual risk reduction at certain sites. This is true at Ciba-Geigy, since the cost is high and the remediation plan fails to call for removal of all the drums. The RCRA needs more technical advice as part of its implementation policy in order to figure out where money needs to be spent or where certain plans will not actually work to reduce health and safety risks. Therefore, RCRA must create remediation plans that are site-specific rather than, a one size fits all approach, so to speak. This law should send the message that quick clean ups are desirable and cost less. The EPA has to concentrate on monitoring each state as it administers its own Program. The federal government should also offer guides that are designed to bolster public awareness. Often, local citizens in the region are unaware that this environmental crisis could happen again so long as the polluted drums are allowed to stay on-site.

\section{The Federal EPA Must Play a Stronger Role}

The EPA is still largely ineffectual. Clearly, politics does play a role as some say it depends on who is in the Whitehouse. Sadly, even after a barrage of legislation had been enacted, the EPA does a fairly marginal job at best. Further, the Ciba-Geigy Superfund site is an example of capitalism run wild where profits were allowed to drive every motivation. The price that the corporation had to pay was very small compared to the price that the families are paying who suffered illness and fatalities. Humanity continues to suffer from pollution that destroys earth's natural resources interfering with sustainability. We do not even know the toll that this has taken on the plants and animals. There were no studies done to measure that, as our environmental laws do not require such studies to be carried out.

\subsection{Shortcomings of Clean-up (Remediation) Efforts}

The clean up efforts fall short of what is really needed since some of the contaminated drums will not be removed from the site as there are 38,000 drums that are not part of any remediation process. They removed 
35,000 drums and those remediation plans ended with regard to the drums in November 2004. The other drums will remain on this site (in a landfill) that is regulated by the State of New Jersey. It contains a liner with a leak detection. The other drums were transported off site to several waste facilities since the drums contained several mixtures of contaminants.

\subsection{EPA Monitoring}

Currently, the EPA monitors air quality daily in several locations of the site. There is not much activity or noise at the site. The people working there wear special equipment and protective suits. There is no interruption in traffic patterns because there is only one one dump truck that leaves the site every day. In fact, most people in town do not pay much attention to the cleanup project. Many local residents do not even know where the site is located.

\subsection{Site Proximity}

The site's close proximity to the elementary school should be of primary concern here. There is an emergency plan in place with the township. The air monitoring equipment is seen throughout the site. Surely, the main worry is that the water is still not safe. The clean up efforts are extensive but further leaching into the groundwater supply is eminent. Currently, the protection of the Aquifer is less stable as EPA officials advise that the thin layer of yellow clay acts as a barrier to minimize contamination. The EPA's perched water management plan is supposed to run for 30 years before contaminants are removed. We have to consider that the remediation process is slow as the problem has been with us for decades, already. The clay layer could and most likely will be compromised, though. It is imprudent to rely on nature's clay layer to protect the aquifer. It is asserted that this remediation plan does not adequately address this issue and the time to act is always through solid preventive measures. The perched water management plan with its containment systems can fail even though these systems are being monitored. Therefore, contaminants can pierce the yellow clay and end up in the aquifer below. Consequently, the pollution and its effects will return and this possibility forestalls environmental sustainability. Sound remediation plans that promote environmental sustainability prevent pollution from happening again and these plans also clean and protect the environmental resources for future generations.

\section{ISRA: Excessive Agency Discretion Cannot Lead to Environmental Sustainability}

The Industrial Site Recovery Act (2006) falls under the New Jersey Environmental Protection Agency and it is primarily in charge of imposing regulations on remediated sites. It does set controls and rules for how hazardous products are stored and handled. It was created to address the after-effects from the state's early industrialization that has left behind significant pollution during what many should consider a license to pollute. As a nation, we industrialized and dumped, and not much thought went into the consequences of dumping or burying toxic waste. This is the time before environmental laws existed and prior to any regulation or study about the ill effects of dumping.

\subsection{Policy Implementation}

ISRA implements the policies that protect the health and safety of New Jersey citizens. It also ensures that sites are cleaned up in a timely manner. One goal is to work with polluters to clean up these sites without unnecessary financial burden. Well, with regard to Ciba-Geigy, it is argued that it is not an unnecessary financial burden to adequately remediate this site by removing all the drums. This is the loophole in the law regarding how remediation should be carried out in New Jersey, because lawmakers through this Act, give the agency too much discretion. While, ISRA has worked hard to ensure our safety and to make sure that remediation projects are not abandoned by polluters, in this case, not enough is being done to protect residents. In short, nothing is being done to safeguard this resource for future generations. Our planet cannot sustain itself and all living things when there is this kind of rampant pollution. A resource such as clean water can only be sustained when it is restored as close to its natural unpolluted state.

\section{Conclusions and Recommendations}

The Industrial Site Recovery Act leaves too much discretion to agency officials and its focus is too concerned with minimizing the state's involvement in these businesses (which are polluters), affairs. The purpose of the Act needs to be changed to include language that shows that the state legislators are concerned about their voter's health and less worried about how much the state is interfering with the campaign fund contributing corporations. The non-intact drums that remain buried at the site need to be accounted for. The other portion of the drums that they were placed in the state regulated landfill need to be removed. The EPA and Ciba-Geigy's solution seemed to be to just remove drums that were in one portion of the site. The EPA and Ciba-Geigy's solution not to remove all the drums is a dangerous and unsound plan. The EPA and Ciba-Geigy hope that no trespassers come onto the land. In fact, trespassers go onto the Ciba-Geigy superfund site to hunt. They need to create a more secure way to keep people out. For example, by erecting a higher fence and more warning and site identification signs. The local adjacent Winding River Park itself is still not safe for children and adults. The air and water quality need to be studied. Until recently, the river inside the park was not tested. In 1987, the river water was contaminated with levels of dyes and pesticides. My recommendations cannot be put to use because the matter is essentially closed. EPA and Ciba-Geigy have made their plans and they are carrying them out. By 2010, the 
entire remediation plan will end. The recommended further study involves the Winding River Park as there needs to be more testing of air and water quality there. They should consider moving the elementary school to another location. It is unsafe for children to be in such close proximity to this or any Superfund site.

A report should also be done to find out the toll that this site and its clean up has taken on the environment. The report should specifically address what has the existence of this site cost in terms of non human life? What has it cost in terms of our feelings of safety and confidence in the water that we drink and the air that we breathe? The report may also want to consider how people's feelings about the EPA may have changed when they learn about these disasters. The government does not deal with personal issues as federal agency reports just address: the raw data, the facts, and the finances. These remediation plans fail to take into account environmental sustainability. There is no consideration for how the land and water on-site will be restored as close as possible to the natural un-polluted state. Remediation plans must address a plan for environmental sustainability so the issues do not become a problem for future generations.

\section{References}

Adams. (2008). Using ADR Principles to Resolve Environmental Disputes: How Mediated Settlements Have Helped Struggling CERCLA Survive, 8 Pepp. Disp. Resol. L.J. 331.

ATSDR. (1988). Public Health Assessment-Ciba-Geigy National Priorities List Site, U.S. Agency for Toxic Substance and Disease Registry, Atlanta: GA.

AWARE. (1985). Ground Water Monitoring Plan for Ocean Outfall-Toms River Plant.

Bagley \& Revesz. (2006). Centralized Oversight of the Regulatory State, 106 Colum. Law Rev. 1260.

Benedict. (2009). Transnational Pollution \& the Efficacy of International \& Domestic Resolutions Among the NAFTA Countries, 15 American Law \& Business Review 863.

Ciba-Geigy v. Township of Dover. (1988). 230 N.J. Super. 317; 553 A2d. 398; N.J. Super. LEXIS 484.

Comprehensive Environmental Response, Compensation \& Liability Act. (2000). 42 U.S.C. 9601-9675.

EPA NPL Listing. (1983). EPA ID No. NJD001502517, all Superfund sites are listed in the Comprehensive Environmental Response Compensation and Liability Information System (CERCLIS) national database.

Final Rule FR 5598. (1991). NPL, Superfund, USEPA, Federal Register Vol. 56, No. 28.

In the Matter of the Issuance of a Permit by the Department of Environmental Protection to Ciba-Geigy Corporation, et, al. v. New Jersey Department of Environmental Protection. (1990). 120 N.J. 164; 576 A2.d 784; 1990 LEXIS 93.

NJDHSS. (1997). Health Consultation: Childhood Cancer Incidence: A Review and Analysis of Cancer Registry Data, 1979-1995 for Dover Township (Ocean County), New Jersey, NJ Department of Health and Senior Services, and Agency for Toxic Substances and Disease Registry.

NUS. (1988). Feasibility Study for the Ciba-Geigy Site, NUS.

Resource Conservation and Recovery Act. (2000). 42 U.S.C. 6901-6992k (amending Solid Waste Disposal Act, Pub. L. No. 89-272, 79a Stat. 992).

Tanck. (2004). Getting Snagged in the Environmental Liability Web: The Trouble with CERCLA and Why the Brownfields Act Provides Only Modest Relief, 35 Tex. Tech. L. Rev. 1325.

Thomas, R. (2009). The European Directive on the Protection of Groundwater: A Model for the United States, 26 Pace Environmental Law Review.

USEPA. (1989). Record of Decision-Ciba-Geigy Corporation Operable Unit 1, USEPA Region 2. 